\title{
THE FINANCIAL EFFECT OF \#FEESMUSTFALL ON INDIVIDUAL TAXPAYERS
}

\author{
Anneke Maré Moolman \\ North-West University Vaal Campus \\ E-mail: Anneke.moolman@nwu.ac.za \\ Orcid no: 0000-0002-4881-0307 \\ Lerike Jacobs \\ North-West University Vaal Campus \\ E-mail: Lerike.jacobs@nwu.ac.za \\ Orcid no: 0000-0002-5955-6658
}

\section{-Abstract -}

The \#FeesMustFall campaign evolved from a demand for lower fees for higher education to fee-free higher education in merely two years, necessitating extensive reconsideration of the state budget. Over the same period, marginal tax rate and value added tax (VAT) increases have been felt by South African individual taxpayers. Therefore an exploratory, document analysis has been performed to determine the extent to which the \#FeesMustFall campaign has been shifted to the individual taxpayer between the 2015 and 2019 years of assessment. The findings indicate that the demand for increased financial support of students led to the recent VAT and marginal tax rate increases, but that tax revenue is actually declining: the VAT increase has partially covered the increase in social grants to protect the poor from the VAT increase, and the marginal tax rate increase is resulting in reduced growth in tax revenue collection as individual taxpayers are overburdened and therefore, tax avoidance is increasing while productivity is decreasing. The present study provides taxpayers with clarity on the recent tax increases and emphasises to National Treasury that any further tax increase would be to the country's detriment.

Keywords: \#FeesMustFall, tax rate increases, VAT increase, tax budget, free higher education

JEL Classification: $\mathrm{H} 20$ 


\section{INTRODUCTION}

The importance of quality education remains undisputed as its benefits include improved sustainability, self-worth, and a quality of life (Department of Higher Education and Training (DHET), 2013). Education ultimately addresses economic needs, thereby driving economic growth (DHET, 2013:2). Mandela was quoted saying that "education is the most powerful weapon which you can use to change the world" (Loo, 2018). In the past, though, access to higher education was restricted due to the high fees related thereto (DHET, 2013:37).

However, the past four years has been marked by several events which, according to Pandor (2018), the Minister of Higher Education and Training, fundamentally influenced the higher education and training (higher education) sector. The initial requests for a reduction in fees became a demand for free education for the poor (Areff \& Spies, 2017; DHET, 2013). The government promised universities to pay most of the resulting shortfalls (Moolman \& Jacobs, 2018), as well as to increase subsidies (Areff \& Spies, 2017), which led to increased tax expenditure.

Over the same period, extensive tax increases have been felt by South African taxpayers to such an extent that Mandy (2018) is of the opinion that South Africa has reached its tax increase limit, specifically for personal income tax (PIT). Mandy (2018) explains that, based on the Laffer curve, the announced tax increases would most probably push tax revenues to a situation where "tax rate increases will actually result in a decrease in tax revenues". This would be due to a decline in productivity, as well as an increase in tax avoidance (Mandy, 2018; Schneider, 2017)

The recent tax increases are described as "a bitter pill to swallow" (Davis, 2018), and most taxpayers feel overburdened (Schneider, 2017), that taxes are maladministered (Davis, 2018), inefficient and wasteful (Du Plessis, 2017; Mandy, 2018) and perceive the government to be corrupt (Davis, 2018; Mandy, 2018), leading to reduced trust in the public sector.

Transparency is key to regain public trust (Porumbescu, 2017). As individuals contribute most of the government's tax revenue (National Treasury, 2017a), it is important for individuals to be informed whether the government utilises their hard-earned money to promote "economic development, good governance, social progress and a rising standard of living for all South Africans", as they promise (National Treasury, 2017b). 


\section{2. \#FEESMUSTFALL TIMELINE}

The \#FeesMustFall campaign commenced in 2013, after a statement by the Department of Higher Education and Training (DHET) that government would consider options of regulating higher education fee increases (DHET, 2013:37). In October 2015, student protests flamed up (Fataar 2015), and led to damage to university infrastructure of about R460 million (News 101, 2016).

On 23 October 2015, President Zuma announced a zero per cent fee increase for public universities for 2016 (Allison, 2015), which led to a R2.33 billion shortfall at these universities (Bernardo, 2015). Seventy to $100 \%$ of this shortfall was covered by the government (Moolman \& Jacobs, 2018), necessitating public universities to cover R396.1 million by themselves (DHET, 2016), of which R200 million related to a single university (Rensburg, 2016). This shortfall led to halting of expansion of infrastructure, furniture, reduced staff costs, as well as student bursaries, scholarships and transport costs at universities (Moolman \& Jacobs, 2018).

However, students were still crying out for assistance with regard to the fees of higher education, and therefore President Zuma appointed a commission of inquiry into higher education (Commission) to provide a report on 14 January 2016, to determine the feasibility of making higher education in South Africa free (The Presidency, 2016).

The report was not issued after ten months as originally intended (The Presidency, 2017), and in the meantime, tuition fee increases were once again halted for the National Student Financial Aid Scheme (NSFAS) qualifying students, as well as students from households earning less than R600 000 per annum (Bateman \& Bendile, 2016). The announcement, made on 19 September 2016, resulted in 2017's university fees equalling 2015's for about $70 \%$ of all students (Bateman \& Bendile, 2016).

After months of thorough research that included a broad range of stakeholders, President Zuma released the Commission's report on 13 November 2017 (The Presidency, 2017). The report stated that fee-free higher education is not feasible in South Africa, but included practical recommendations to ensure the promotion of access to universities of poor and middle class students.

However, the report was disregarded when President Zuma announced free higher education for the poor on 16 December 2017, which would commence in 2018. Poor students include students from households earning less than R350 000 per 
annum (Areff \& Spies, 2017). President Zuma also promised a subsidy to universities to ensure no increase for students from households that earn between R350 000 and R600 000 per annum. R57 billion was set aside to fund this system in the medium term (Personal Finance, 2018). In addition to these unexpected promises made, President Zuma undertook to increase the subsidies to universities from $0.68 \%$ to $1 \%$ of the gross domestic product (GDP) over the next five years, as suggested by the Commission (Areff \& Spies, 2017).

On 16 January 2018, Finance Minister Gigaba stated that the 2018 budget would communicate how free higher education would be funded (Groenewald \& Mitchley, 2018).

\section{TAX INCREASE TIMELINE}

South Africa's tax revenue consist out of PIT, value added tax (VAT), corporate income tax (CIT), customs and excise duties, fuel levies and other (National Treasury, 2018a). About $80 \%$ of tax revenue is made up of PIT, VAT and CIT (National Treasury \& South African Revenue Service (SARS), 2017:8), while PIT is the prevalent contributor at $38 \%$ of the tax revenue (National Treasury, 2018b).

South Africa applies a progressive income tax system (Zanten, 2016:57) for PIT, which is rated as the best tax system in the world (Bateman, 2017). Since the initiation of \#FeesMustFall in 2013, the marginal tax rate for individual taxpayers increased from $40 \%$ for the 2014 year of assessment (SARS, 2018b) to $45 \%$ for the 2018 year of assessment (SARS, 2018b). Finance expert, Coomer (2017), indicated that only $13 \%$ of people of the population of 56 million in South Africa contribute to PIT. Only 480000 of these taxpayers earn more than R750 000 per year (Coomer, 2017), contributing about 50\% to PIT (Schneider, 2017).

PIT payers are also responsible for most of the VAT (Coomer, 2017), that contributes $25 \%$ to tax revenue (Coomer, 2017; National Treasury, 2018b). Affluent households contribute $85 \%$ of VAT revenue (Ensor, 2018). VAT was introduced in 1991 and levied at a constitutional rate of 10\%, increased to $14 \%$ in 1993 (Go, Kearney, Robinson \& Thierfelder, 2004; National Treasury, 2018b:42) and increased another percentage point to $15 \%$ for the 2019 year of assessment (Cronje, 2018).

Graph-1 displays the growth rates in PIT and VAT applicable to individual taxpayers for the years of assessments under review: 2015 to 2019. 
Graph-1: PIT marginal rates and VAT rates applicable for the 2015 to 2019 years of assessment

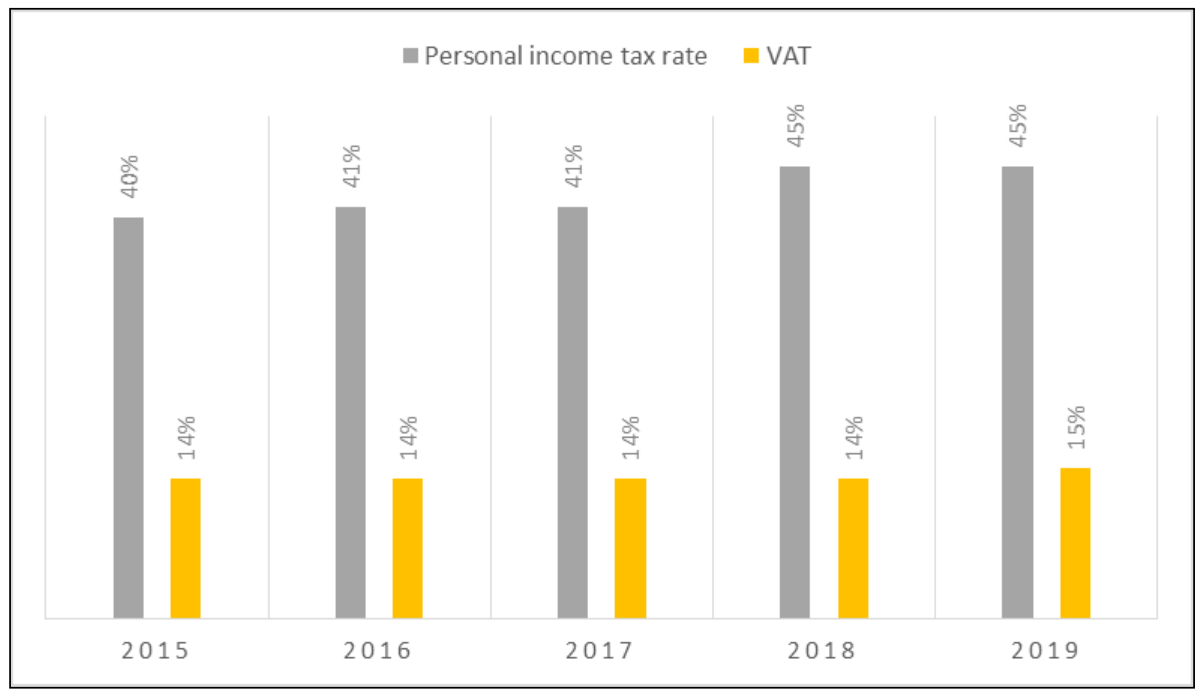

Source: SARS (2018a)

Even with the increases in PIT and VAT, government anticipated a revenue shortfall of R48.2 billion during the 2018 year of assessment (National Treasury, 2018b:37).

\section{PROBLEM STATEMENT}

The last four years have been marked by events relating to ultimate fee-free higher education to the poor, as well as extensive tax increases. Individuals are responsible for the largest portion of South Africa's tax revenue and are overburdened by taxes. As transparency is necessary to build trust in the public sector, it is paramount to understand whether the increased taxes have been utilised by the government towards quality education, and ultimately economic growth.

\section{RESEARCH METHODOLOGY}

Schoonenboom and Johnson (2017:108) explain that when a qualitative and a quantitative research component are combined, it is referred to as a mixed method design. In this study, an order was followed where literature was utilised to understand the events relating to fees of higher education during the 2015 to 2019 years of assessments, as well as the tax increases to individuals during the same period (the qualitative component). Thereafter, tax revenue related to the 
individual taxpayer, as well as expenditure related to higher education for the 2015 to 2019 years of assessment were graphically analysed in Excel to determine whether the individual taxpayers' tax increases were due to the increase in governmental expenditure towards higher education (the quantitative component). This was supported by an exploratory documentary analysis of the related income from individual taxpayers and the spending of government towards higher education (another qualitative component). Therefore, a partially mixed sequential dominant status design was followed (Leech \& Onwuegbuzie, 2009).

The target population is the 2015 to 2019 years of assessment budget reviews and was obtained from the National Treasury's website. For income figures, the actuals for the 2015 to 2017 years of assessment were used, along with the revised estimate for 2018 and the budget estimate after tax proposals for 2019. For expenditure figures, the revised estimates for the 2015 to 2018 years of assessment were used, while medium-term expenditure estimates were used for 2019. The 2015 year of assessment's budget was used as a benchmark as the first event that had an effect on the fees of higher education only occurred during the 2016 year of assessment as discussed in Section 2.

The cost of living of PIT payers is constantly increasing (Dube, 2017) and government needs to take the Consumer Price Index (CPI) into consideration when compiling the National Budget (Fin24, 2018). For this reason, it is important to compare government income and spending with the average CPI for each year of assessment under review. The CPI rates used for 2015 to 2018 are the actual rates for the corresponding years of assessment, while for 2019; it was based on the actual CPI for the two months, March and April 2018.

\section{FINDINGS AND RESULTS}

During the 2016 year of assessment, a high PIT growth of $9.96 \%$ was experienced in comparison with a CPI of 5\% (see Graph-2). This is due to the increase in the marginal tax rate to $41 \%$, which was most probably a result of the first major announcement relating to no fee increases for higher education during the same period. Even though the marginal tax rate was further increased to $45 \%$ for the 2018 year of assessment, year-on-year PIT growth declined to $8.6 \%$. This may be an indication of reduced production and/or tax avoidance due to the increased tax rates (Mandy, 2018; Schneider, 2017). Government made a wise decision not to increase the PIT rate for the 2019 year of assessment, as an increase would limit economic growth and investment (National Treasury, 2018b:43). 
INTERNATIONAL JOURNAL OF ECONOMICS AND FINANCE STUDIES

Vol 11, No 1, 2019 ISSN: 1309-8055 (Online)

Graph-2: Year-on-year growth in PIT for the 2015 to 2019 years of assessment

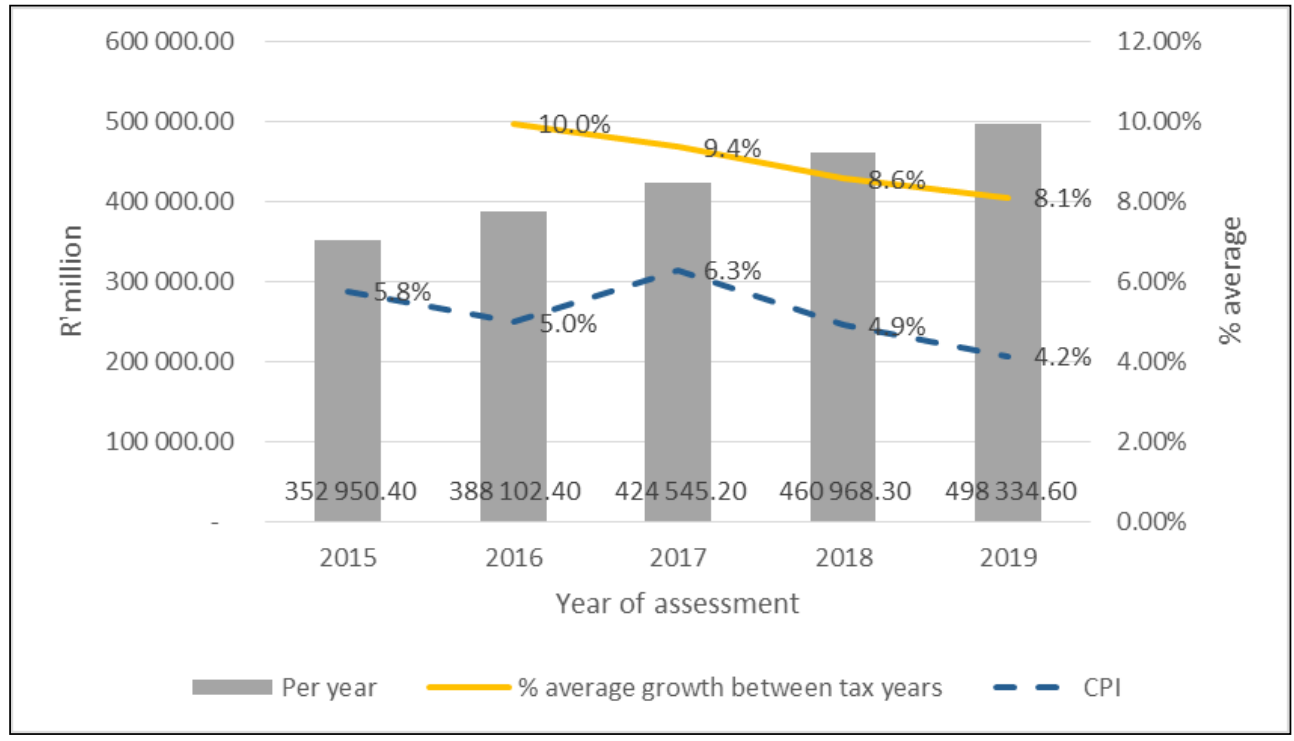

Source: National Treasury $(2015-2018)$

With reference to Graph-3, a steep decline in the VAT growth was experienced during the 2017 year of assessment due to a decrease in the net VAT collected. This was a result of modest growth in household expenditure, shrinkage in the growth of imports and an increase in VAT refunds (SARS, 2017). Households were clearly already pressured by the economy.

For the 2019 year of assessment, a sharp increase in VAT growth is clear, which is due to the one percentage point increase in VAT. VAT is an indirect tax and avoidance thereof is harder than with PIT.

One of the main concerns with the increase in the VAT rate was that it would hit the poor the hardest (Ensor, 2018). For this reason, government increased the social grant to "allow for an above-inflation increase" (Ensor, 2018) and it is expected that social grants will increase with an average annual rate of $7.9 \%$ over the next three years (National Treasury, 2018b). VAT grew by R26 billion from the 2018 to 2019 year of assessment (National Treasury, 2018b), while the social grants were increased by R2.9billion over the same period to protect the poor from the VAT increase (Ensor, 2018). Another reason for the increase in VAT is that it 
INTERNATIONAL JOURNAL OF ECONOMICS AND FINANCE STUDIES

Vol 11, No 1, 2019 ISSN: 1309-8055 (Online)

was necessary to meet new spending commitments, like fee-free higher education (Dentlinger, 2018).

\section{Graph-3: Year-on-year growth in VAT for the 2015 to 2019 years of assessment}

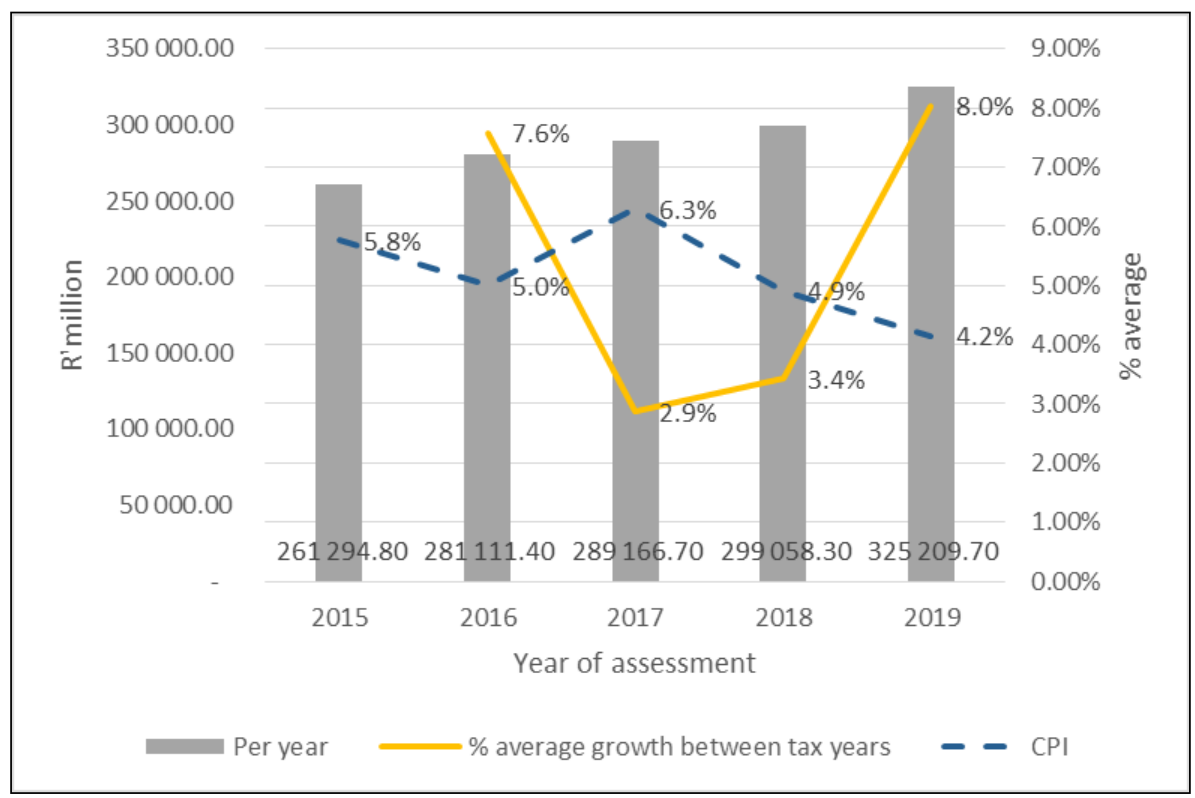

Source: National Treasury (2015 - 2018)

Learning and culture, which include post-school education is the largest expense for government in the 2019 budget (National Treasury, 2018a). Fee-free education increased the total allocation of expenditure to learning and cultural expenditure from roughly $15 \%$ to $21 \%$.

Graph-4 clearly illustrates the spikes in growth in post-school education expenditure for the 2016 year of assessment (when a zero per cent increase was announced) and the 2018 year of assessment (when free higher education to the poor was announced). The expenditure on post-school education increased mainly due to fee-free education (National Treasury, 2018b:58). 
Graph-4: Year-on-year growth in post-school education for the 2015 to 2019 years of assessment

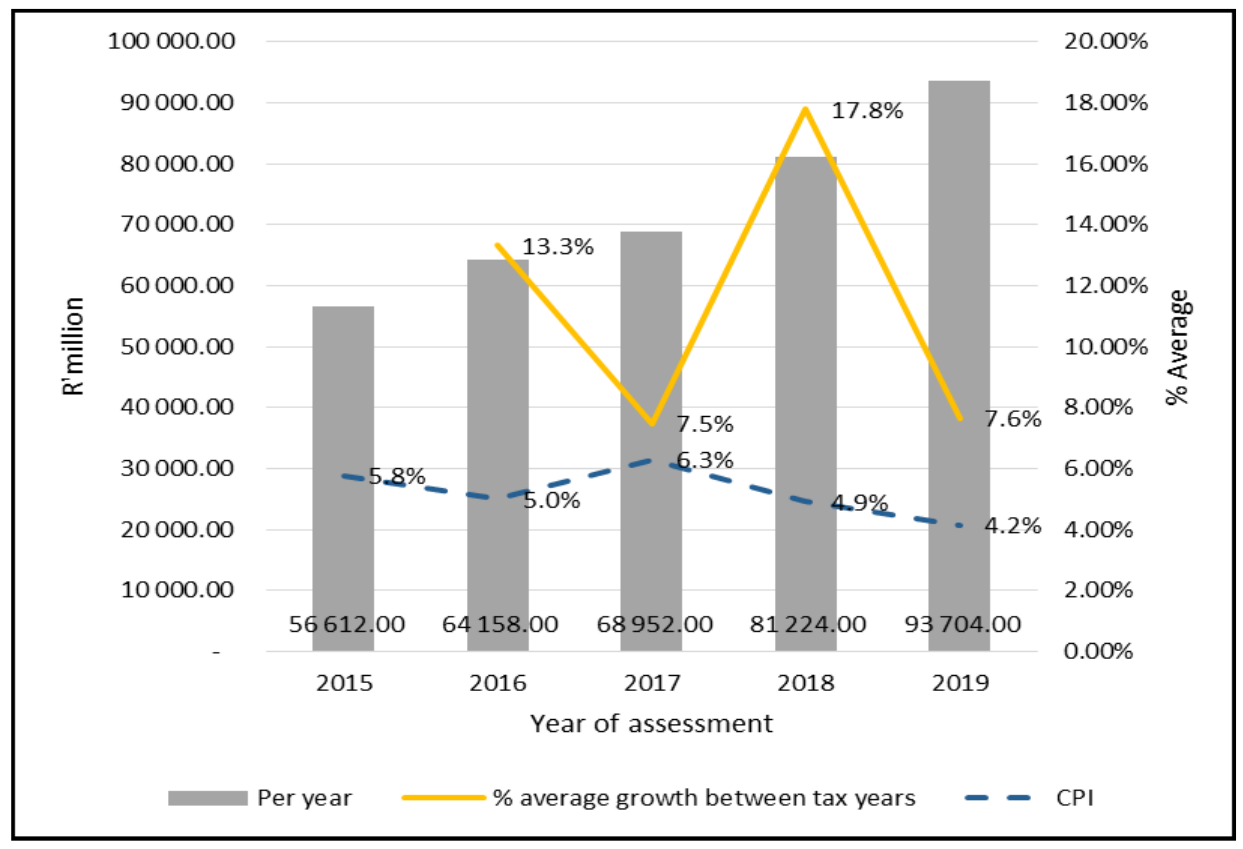

Source: National Treasury (2015 - 2018)

A major problem is that tax expenditure exceeds tax revenue. During the 2016 year of assessment, the government spent more money on repaying government debt and interest than servicing the population through housing, police, hospital and higher education (Stats SA, 2017). During the years to follow, government borrowings increased even further, leading to high debt-service costs (see Graph5 ). Government estimates that by the 2021 year of assessment nearly $15 \%$ of tax revenue will go towards paying of debt (Leuvennink, 2017).

In order to address this, government's intention is to hold back on some capital projects and reduce spending on goods and services (Harmse, 2018). During the 2017 year of assessment the total expenditure ceiling was cut by a total of R25 billion over three years (BusinessTech, 2016). The average growth rate of tax expenditure has declined for the 2015 to 2019 years of assessments, although it mostly exceeds CPI. 
INTERNATIONAL JOURNAL OF ECONOMICS AND FINANCE STUDIES

Vol 11, No 1, 2019 ISSN: 1309-8055 (Online)

Graph-5: Year-on year growth in debt-service cost for the 2015 to 2019 years of assessment

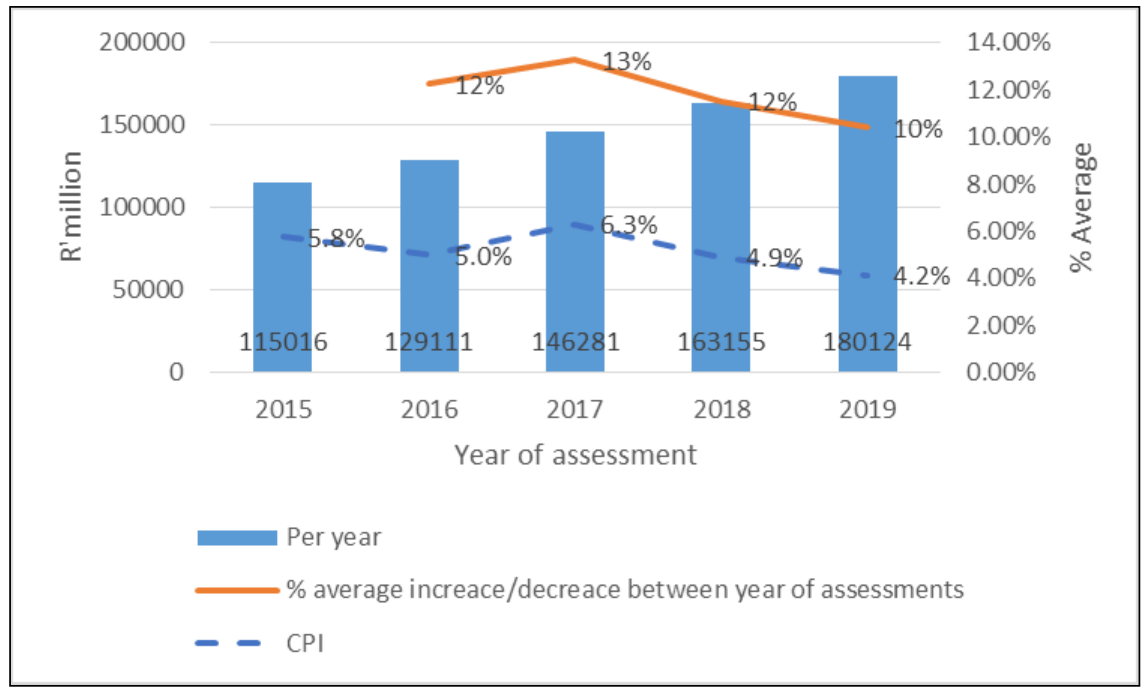

Source: National Treasury $(2015-2018)$

Overall, the five year period from the 2015 to the 2019 years of assessment, shows a tax revenue increase of 33\% while total government expenditure increased with 34\% (see Graph-6), explaining the high government debt and related debt-service cost.

Tax revenue, PIT, tax expenditure, as well as higher (post-school) education and debt-service cost expenditure significantly exceeded the CPI growth for the same period of $26.1 \%$. Although post-school education's growth was by far the most paranormal at $66 \%$, debt-service cost exceeds that of post-school education. 
Graph-6: Increase in government revenue and expenditure for the five year period 2015 to 2019 years of assessment

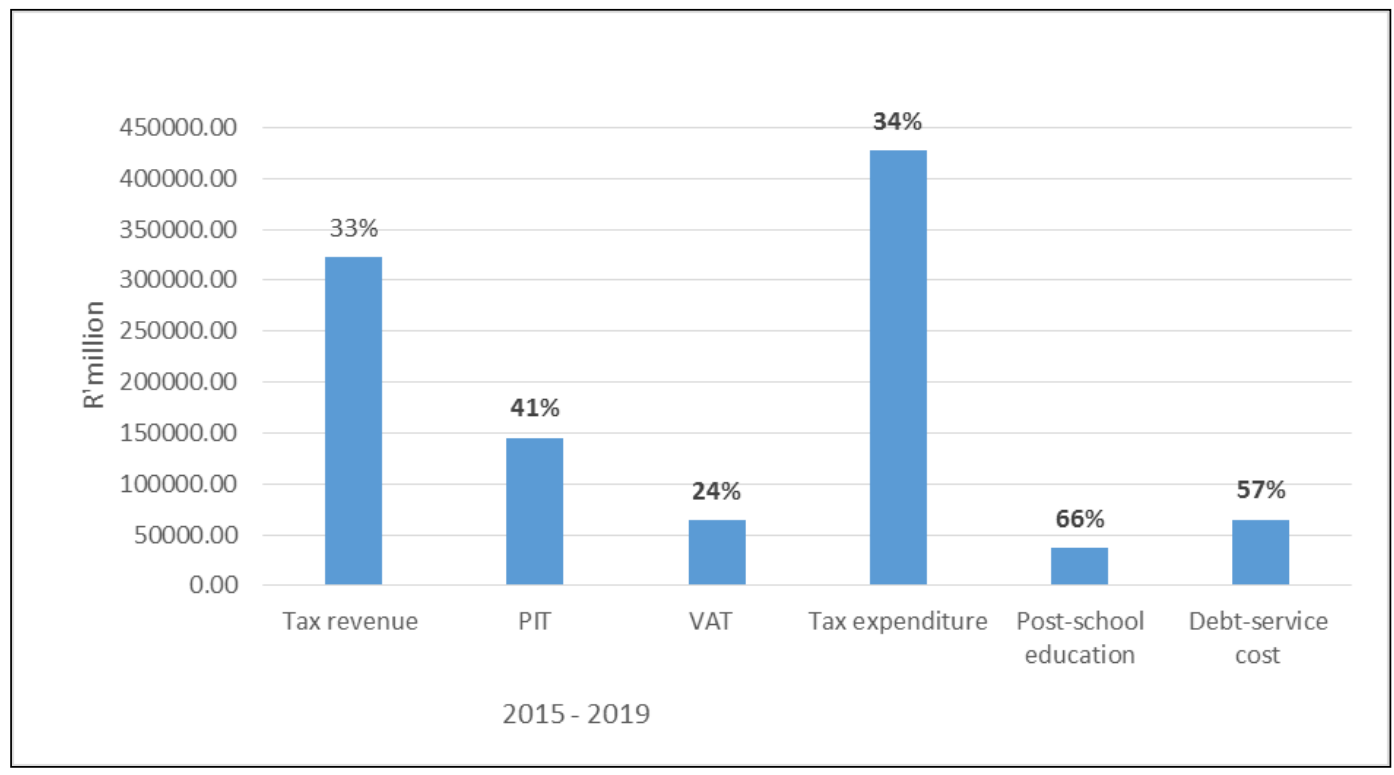

Source: National Treasury $(2015-2018)$

\section{CONCLUSION}

The \#FeesMustFall campaign forced the government to take action to increase access to higher education institutions to poor and middle class students. At first, zero per cent fee increases were announced, which later transformed to free higher education to the poor. The government was necessitated to increase funding to public universities, pressurising the tax budget.

BusinessTech (2017) stated that the most obvious method to fund free higher education to the poor would be to increase PIT, CIT and VAT. The individual taxpayer therefore experienced subsequent PIT and VAT increases.

About $10 \%$ of the increased revenue from VAT is consumed by an increase in social grants to protect the poor from the VAT increase, and the rest aids in covering higher education expenditure. The initial increase in the marginal tax rate assisted the funding of the zero per cent fee increase in higher education.

However, South Africa had thereafter reached the tipping point, where further tax increases would actually lead to a decline in tax revenue due to an increase in tax avoidance and decreased productivity as individual taxpayers feel overburdened and that their hard-earned monies are not utilised effectively towards "economic 
development, good governance, social progress and a rising standard of living for all South Africans" as is promised by National Treasury (2017b).

If the government is able to reduce tax expenditure below tax revenue, government debt will decrease, ultimately eradicating debt-service cost, which is not adding value for South Africa's citizens.

Opportunities for further research may include proposals to optimise the utilisation of the available pool of tax revenue, as well as to reduce tax expenditure.

\section{REFERENCE LIST}

Allison, S. 2015. \#FeesHaveFallen: A big day in Pretoria, with a Zero outcome. http://www.dailymaverick.co.za/article/2015-10-23-feeshavefallen-a-big-day-inpretoria-with-a-zero-outcome/\#.V5M7kqIj4WA. Accessed 2016/07/23.

Areff, A. \& Spies, D. 2017. Zuma announces free higher education for poor and working class students. https://www.news24.com/SouthAfrica/News/zumaannounces-free-higher-education-for-poor-and-working-class-students-20171216. Accessed 2018/05/18.

Bateman, B. \& Bendile, D. 2016. University councils likely to implement $8 \%$ fee increase. http://ewn.co.za/2016/09/19/University-councils-likely-to-implement-8percent-fee-increase. Accessed 2016/11/21.

Bateman, C. 2017. SA has world's most progressive tax structure-but it's not reducing poverty. https://www.biznews.com/in-focus/2017/07/25/sa-progressivetax-structure-oxfam/. Accessed 2018/06/20.

Bernardo, C. 2015. 0\% increase may cost state R2.4 billion.

http://www.iol.co.za/news/politics/0-increase-may-cost-state-r24-billion-1940592. Accessed 2016/07/23.

BusinessTech. 2016. The 2016 SA budget in a nutshell. https://businesstech.co.za/news/finance/114048/here-is-the-2016-budget-in-anutshell/. Accessed 2018/06/22.

BusinessTech. 2017. What the fees commission says about using your taxes to fund free university. https://businesstech.co.za/news/finance/210565/what-thefees-commission-says-about-using-your-taxes-to-fund-free-university-in-sa/. Accessed 2018/06/21. 
Coomer, J. 2017. This is who is paying South Africa's tax. https://businesstech.co.za/news/finance/207631/this-is-who-is-paying-southafricas-tax/. Accessed 2018/06/20.

Cronje, J. 2018. South Africans to pay higher VAT for first time in two decades. https://www.fin24.com/Budget/south-africans-to-pay-higher-vat-for-first-time-intwo-decades-20180221. Accessed 2018/06/21.

Davis, R. 2018. Budget 2018: Tax increases set to hit ordinary South Africans hard. https://www.dailymaverick.co.za/article/2018-02-22-budget-2018-taxincreases-set-to-hit-ordinary-south-africans-hard/\#.WxZtjIq-nIU. Accessed 2018/06/05.

Dentlinger, L. 2018. Govt's new spending commitments to hit large municipalities. http://ewn.co.za/2018/02/22/govt-s-new-spending-commitmentsto-hit-large-municipalities. Accessed 2018/06/22.

Department of Higher Education and Training. 2013. White paper for postschool education and training.

http://www.dhet.gov.za/SiteAssets/Latest $\% 20$ News/White $\% 20$ paper $\% 20$ for $\% 20 p$ ost-school\%20education\%20and\%20training.pdf. Accessed 2016/07/28.

Department of Higher Education and Training. 2016. Ministers Nzimande and Nhleko agree on the urgent need for the establishment of the rule of law on South African campuses. https://www.wits.ac.za/media/wits-university/news-andevents/documents/Nzimande\%20Nhleko\%20on\%20Campus\%20Disturbances.pdf . Accessed: 2016/05/23.

DHET see Department of Higher Education and Training.

Du Plessis, C. 2017. Gordhan prepares for tough budget speech. https://mg.co.za/article/2016-02-18-gordhan-prepares-for-tough-budget-speech/. Accessed 2017/04/25.

Dube, N. 2017. Tough times ahead as cost of living soar. https://www.news24.com/SouthAfrica/Local/Stanger-Weekly/tough-times-aheadas-costs-of-living-soar-20171101. Accessed 2018/06/25.

Ensor, L. 2018. Budget 2018 in a nutshell: first VAT increase in 25 years. https://www.businesslive.co.za/bd/economy/2018-02-21-budget-2018-in-anutshell-first-vat-increase-in-25-years/. Accessed 2018/06/21. 
Fataar, A. 2015. Why the fees must fall. Socialistworker.org October 27. https://socialistworker.org/ 2015/10/27/why-the-fees-must-fall. Accessed 2016/07/23.

Fin24. 2018. Rand volatile as all eyes turn to National Budget. https://www.fin24.com/Budget/rand-volatile-as-all-eyes-turn-to-national-budget20180221. Accessed 2018/06/25.

Go, D.S., Kearney, M., Robinson, S. \& Thierfelder, K. 2004. An analysis of South Africa's Value Added Tax. CiteSeerX.

Groenewald, Y. \& Mitchley, A. 2018. Plans for free higher education on trackGigaba. https://www.fin24.com/Economy/plans-for-free-higher-education-ontrack-gigaba-20180116. Accessed 2018/05/18.

Harmse, J. 2018. Be Informed: The Impact of Free Education. https://educonnect.co.za/informed-impact-free-education/. Accessed 2018/06/22.

Leech, N.L. \& Onwuegbuzie, A.J. 2009. A typology of mixed methods research designs. Quality \& quantity, 43(2):265-275.

Leuvennink, J. 2017. Mounting debt-service costs crowd out social and economic spending. https://www.fin24.com/Budget/Budget-andEconomy/mounting-debt-service-costs-crowd-out-social-and-economic-spending20171025. Accessed 2018/06/25.

Loo, C. 2018. Top Nine Nelson Mandela Quotes About Education. https://borgenproject.org/nelson-mandela-quotes-about-education/. Accessed 2018/09/06.

Mandy, K. 2018. Has South Africa reached its limit on tax increases? https://www.pwc.co.za/en/press-room/south-africa-reached-limit-on-taxincreases.html. Accessed 2018/06/04.

Moolman, A. \& Jacobs, J. 2018. Responses to the short-term effect of the zero per cent fee increase on South African universities. South African Journal of Higher Education, 32(1):178-191.

National Treasury. 2017a. National Treasury budget highlights. http://www.treasury.gov.za/documents/national\%20budget/2017/sars/Budget $\% 20$ 2017\%20Highlights.pdf. Accessed 2017/05/02.

National Treasury. 2017b. The role of the National Treasury. http://www.treasury.gov.za/nt/info.aspx. Accessed 2017/05/05. 
INTERNATIONAL JOURNAL OF ECONOMICS AND FINANCE STUDIES

Vol 11, No 1, 2019 ISSN: 1309-8055 (Online)

National Treasury. 2018a. 2018 Budget Highlights. National Treasury.

National Treasury. 2018b. 2018 Budget Review. National Treasury.

National Treasury \& SARS. 2017. Tax Stats 2017.

News101. 2016. Estimated R460 million cost of damage during \#FeesMustFall protest. http://www.news101.co.za/2016/06/09/estimated-r460-million-costdamage-feesmustfall-protest/. Accessed 2016/07/23.

Pandor, G.N.M. 2018. Minister Pandor's speech introducing the Department of Higher Education and Training's 2018 Budget Vote. http://www.dhet.gov.za/. Accessed 2018/06/05.

Personal Finance. 2018. Free higher education kicks in immediately. https://www.iol.co.za/personal-finance/free-higher-education-kicks-inimmediately-13468587. Accessed 2018/05/18.

Porumbescu, G. 2017. Linking transparency to trust in government and voice. The American Review of Public Administration, 47(5):520-537.

Rensburg, I. 2016. Communiqué by Prof Ihron Rensburg to parents/guardians of UJ students.

http://www.uj.ac.za/newandevents/Pages/Communiqu\%C3\%A9-by-Prof-Ihron-Re nsburg-toparents--guardians-of-UJ-Students.aspx. Accessed 2016/05/23.

SARS see South African Revenue Service.

Schneider, F. 2017. The Burden of the South African Taxpayer and Tax Freedom Day. https://www.bdo.co.za/en-za/insights/2017/tax/the-burden-of-the-southafrican-taxpayer-and-tax-freedom-day. Accessed 2018/06/21.

Schoonenboom, J. \& Johnson, R.B. 2017. How to Construct a Mixed Methods Research Design. KZfSS Kölner Zeitschrift für Soziologie und Sozialpsychologie, 69(2):107-131.

SARS. 2017. SARS announces the preliminary outcome of revenue collections for 2016/17. http://www.sars.gov.za/Media/MediaReleases/Pages/03-April-2017--SARS-revenue-collection-2017.aspx. Accessed 2018/06/22.

SARS. 2018a. Income tax rates. http://www.sars.gov.za/Tax-Rates/IncomeTax/Pages/default.aspx. Accessed 2018/06/25. 
SARS. 2018b. Rates of tax for individuals. http://www.sars.gov.za/TaxRates/Income-Tax/Pages/Rates\%20of\%20Tax\%20for\%20Individuals.aspx. Accessed 2018/06/20.

Stats SA. 2017. Infographic: Government's spending priorities. http://www.statssa.gov.za/?p=10730. Accessed 2018/06/21.

The Presidency. 2016. President Zuma announces commission of inquiry into Higher Education Funding and other issues. http://www.dhet.gov.za/SiteAssets/Latest\%20News/January\%202016/PRESIDEN T\%20ZUMA\%20ANNOUNCES\%20COMMISSION\%20OF\%20.pdf. Accessed $2018 / 05 / 18$.

The Presidency. 2017. Release of the Report of Commission of Inquiry into the Feasibility of making Higher Education and Training fee-free in South Africa. http://www.thepresidency.gov.za/press-statements/release-report-commissioninquiry-feasibility-making-high-education-and-training. Accessed 2018/05/18.

Zanten, M.V. 2016. Tax Collection Policies: A comparison between antiquity and modern South Africa. University of Pretoria. 